\title{
Removal of Mixed Azo Dyes by a Moderately Alkaliphi- lic Bacterial Strain Isolated from Textile Effluent Con- taminated Site
}

\begin{abstract}
Keywords: Azo dyes; Textile effluent; Direct Brown; Direct Yellow; Alkaliphilic; Decolourization

\section{Abstract}

The aim of the present study was to isolate an alkaliphilic bacteria strain from textile effluent contaminated site and to investigate the ability of the bacterial strain to decolorize the mixed dyes, Direct Brown MR and Direct Yellow SG at different concentrations. The enriched moderately alkaliphilic bacterial strain could decolorize mixed azodyes (DB MR and DY SG) at different concentrations (50 to $250 \mathrm{mg} / \mathrm{L}$ ). The bacterial strain exhibited maximum decolourization ability of mixed dyes at $\mathrm{pH}$ 9, at a concentration of $150 \mathrm{mg} / \mathrm{L}(90 \%)$ of DB MR and DY SG which showed the maximum degradation of $90 \%$ by the end of 5 th day, at an optimum temperature at $28^{\circ} \mathrm{C}$. Supplementing the media with sucrose and yeast extract, as carbon and nitrogen source could enhance the dye decolourization efficiency of the isolated bacteria strain. The isolated mixed dye degrading bacterial strain was identified by 165 rRNA sequencing as Serratia marcescens. Such isolated bacterial strain could be applied to biological systems for the effective removal of these mixed dyes from textile effluent wastewater.
\end{abstract}

\section{Introduction}

Our biosphere is under constant threat from continuing environmental pollution. Impact on its atmosphere, hydrosphere and lithosphere by anthropogenic activities on air, water and land have a negative influence over biotic and abiotic components of the natural ecosystems. Among the various industrial sectors, the textile and paper industries are especially challenging since they generate significant quantities of wastewater that may have detrimental impacts when released into the environment without any treatment. Textile wastewater is one of the most polluted of the wastewaters due to the lag large variety of dyes and chemical additions contained in it, which complicates further treatment of the textile wastewater. Azo dyes are mostly used in textile industry due to their extensive variety of colour shades and brilliant colours but they are recalcitrant xenobiotics. They are a common classification of dyes, accounting for between $60-80 \%$ of all dyes. This class of dyes gives off bold colours in a variety of hues [1].

In order to achieve satisfactory and acceptable quality levels that allow recycling of textile wastewater, removal of dyes and related compounds is very crucial. Based on the fact that also dyes constitute the largest percentage of textile dyes, most treatment methods are based on the decolourization of azo dyes [2]. Physical methods include traditional physical-chemical technique such as ultra filtration, reverse osmosis, ion exchange and adsorption
Journal of

Microbiology \& Microbial Technology

\section{Rishika Lalith Kumar and Veena Gayathri Krishnaswamy*}

Department of Biotechnology, Stella Maris college, Chennai, Tamilnadu, India

*Address for Correspondence:

Veena Gayathri Krishnaswamy, Department of Biotechnology, Stella Maris college, Chennai, Tamilnadu - 600086, India, E-mail: veenagayathri@yahoo.com

Submission: 05 May, 2016

Accepted: 13 June, 2016

Published: 17 June, 2016

Copyright: ๑ 2016 Kumar RL, et al. This is an open access article distributed under the Creative Commons Attribution License, which permits unrestricted use, distribution, and reproduction in any medium, provided the original work is properly cited.

on various adsorbents (activated carbon, peat, fly ash, and coal, wood chips, and corncob). Adsorption techniques are more popular due to theirs Efficient in the removal of pollutants too stable for conventional methods [3]. Widely used techniques in Chemical methods include oxidation reactions, photochemical oxidations and electrochemical treatment of which, oxidation processes are the most common [4-6]. This is primarily due to its simplicity of application with hydrogen peroxide being the main oxidizing agent. Chemical oxidation removes the dye from the dye-containing effluent by oxidation, resulting in aromatic cleavage of the molecules [1]. Other newer emerging techniques which include oxidation with Fenton's reagent photo catalysis, and ozonation have shown great potential for effectively removing dyes from wastewaters [7]. These techniques, however, involve complicated procedures and are economically unfeasible for application on a commercial scale [8]. Use of ultra-violet light in photo catalysis is not effective for dark coloured effluents as the UV cannot penetrate the depth of the waste water. Chemical treatment methods also pose a serious threat of introducing secondary pollution due to excessive chemical use [9].

The Biological methods involving microbial decolourization of azo dyes has been of much interest, since it is inexpensive, ecofriendly and produces a less amount of sludge [10,11]. Most of the azo dyes are difficult to degrade because azo bonds in the dyes are resistant to breakdown, with the potential for the persistence and accumulation of high-levels of dye in the environment.

Options for biological treatment of textile effluent may be single phase aerobic or anaerobic or a combination of the both aerobic and anaerobic treatment. Under aerobic conditions the azo dyes are nondegradable by most of the bacteria. Anaerobic biological treatment makes use of the anaerobic bacteria decomposed organic matter in anaerobic conditions. They are very stable in acidic and alkaline conditions and are resistant to temperature and light.

As dyeing effluents are characterized by high levels of alkalinity and salinity, the application of extremophilic microorganisms is 
Citation: Kumar RL, Krishnaswamy VG. Removal of Mixed Azo Dyes by a Moderately Alkaliphilic Bacterial Strain Isolated from Textile Effluent Contaminated Site. J Microbiol Microb Technol 2016;1(1): 9.

inevitable for practical bio-decolourization process as they are able to sustain the stringent conditions of textile dyeing effluents [12]. A novel biological decolourization system consisting of one or more acclimatized dye degrading organisms in optimized concentration is needed [5]. Under aerobic conditions the azo dyes are non-degradable by most of the bacteria. Anaerobic biological treatment makes use of the anaerobic bacteria decomposed organic matter in anaerobic conditions. They are very stable in acidic and alkaline conditions and are resistant to temperature and light.

A number of microorganisms have been found to decolorize textile dyes including bacteria, fungi, and yeasts from concentration 50 - $300 \mathrm{mg} / \mathrm{L}$ [13]. They have developed enzyme systems for the decolourization and mineralization of azo dyes under certain environmental conditions [14]. The extracellular enzyme system includes Laccase (EC 1.10.3.2), Manganese peroxidase (MnP, EC 1.11.1.13), Lignin peroxidase (LiP, EC 1.11.1.14) that are able to decolorize various dyes of different chemical structures [15].

Thus, this study focuses on aerobic decolourization of mixed azo dyes by alkaliphilic bacterial strain isolated from textile effluent contaminated soil. The study was designed to decolourize mixed azo dyes by the isolated bacterial strain at various concentrations. The bacterial strain was optimized for its growth conditions for the effective removal of mixed azo dyes (Direct Brown MR and Direct Yellow SG). Further the bacterial strain was biochemically characterized and identified by $16 \mathrm{~S}$ rRNA sequencing.

\section{Materials and Methods}

\section{Dyes and chemicals}

The textile dyes (azo dye compounds), Direct Brown MR and Direct Yellow SG, were purchased from the local textile industry, Chennai, Tamilnadu. Figure 1 shows the structure of the Azo dyes used in the study. Nutrient agar media and all other chemicals used in mineral salt medium (MSM) preparation were of analytical grade and purchased from Merck, India.

\section{Sample collection}

Soil samples were collected from different areas of effluent contaminated sites of textile industries in Chennai. Samples were collected and transferred to sterile zip lock covers and immediately transported to the laboratory.

\section{Acclimatization of the bacterial Strain and culture conditions}

The bacterial strain was enriched in MSM amended with

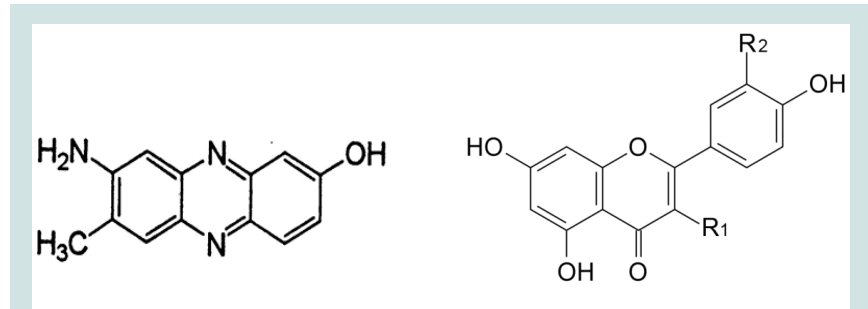

(A)

(B)

Figure 1: (A) Direct Brown MR

(B) Direct Yellow SG

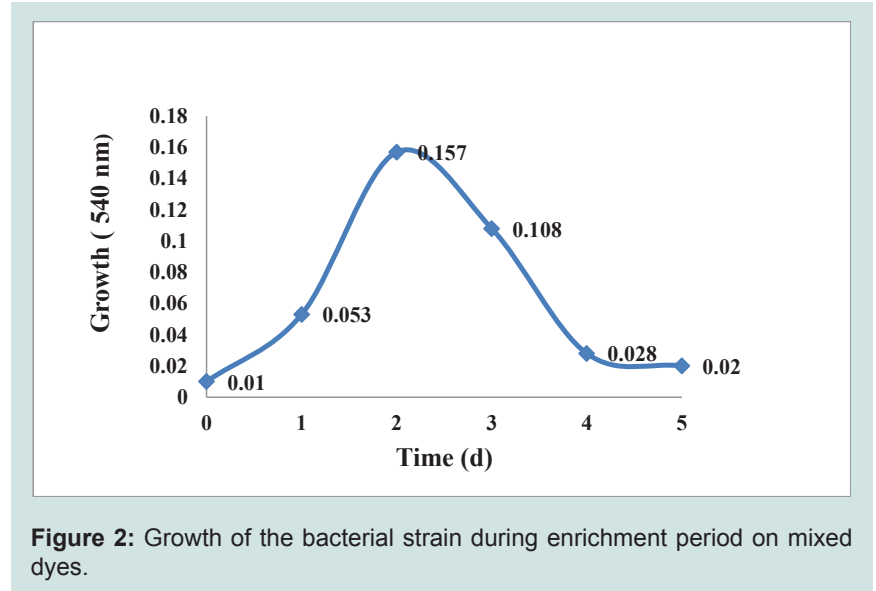

$100 \mathrm{mg} / \mathrm{L}$ of of filter sterilized DB MR and DY SG dyes in a sterilized $250 \mathrm{ml}$ conical flask containing the MSM and incubated in a shaker at $37^{\circ} \mathrm{C}$. The composition of the MSM ( $\mathrm{pH} 9$ ) used for enrichment and decolourization was as follows: Na2HPO4: $12.8 \mathrm{~g} / \mathrm{L} ; \mathrm{KH} 2 \mathrm{PO} 4: 3 \mathrm{~g} / \mathrm{L}$; NH4Cl: 1 g/L; NaCl: 0.5 g/L; 0.05 M MgSO4: 10 mL/L; 0.01 M CaCl2: $10 \mathrm{~mL} / \mathrm{L}$; and $20 \%$ glucose: $30 \mathrm{~mL} / \mathrm{L}$. The MSM was autoclaved, cooled, and then amended with $100 \mathrm{mg} / \mathrm{L}$ of filter sterilized azo dyes DB MR and DY SG in a $250 \mathrm{~mL}$ Erlenmeyer flask respectively. About $10 \mathrm{~g}$ of soil sample was aseptically inoculated into the medium. Individual bacterial isolates were obtained from the enriched culture by plating on nutrient agar medium containing $100 \mathrm{mg} / \mathrm{L}$ of the mixed azo-dyes. The isolated bacterial strain was purified by streaking on nutrient agar added with $100 \mathrm{mg} / \mathrm{L}$ of the mixed dyes. The single colony pure cultures were stored in $15 \%$ glycerol at $-20^{\circ} \mathrm{C}$.

\section{Growth of the bacterial strain}

Sterilized $100 \mathrm{ml}$ of MSM was amended with DB MR and DY SG dyes of mixed dyes at concentrations of $50 \mathrm{mg} / \mathrm{L}$ to $250 \mathrm{mg} / \mathrm{L}$ $(50 \mathrm{mg} / \mathrm{L}, 100 \mathrm{mg} / \mathrm{L}, 150 \mathrm{mg} / \mathrm{L}, 200 \mathrm{mg} / \mathrm{L}$ and $250 \mathrm{mg} / \mathrm{L}) .1 \mathrm{ml}$ of overnight culture was added to each flask and incubated in a shaker at $37^{\circ} \mathrm{C}$. Growth OD at $540 \mathrm{~nm}$ was observed at 24 hours interval till the $5^{\text {th }}$ day, to observe the growth pattern of the bacterial strain. Growth of the bacterial strain was also confirmed through total protein estimation and was observed till the $5^{\text {th }}$ day.

\section{Decolourization of mixed dyes}

Decolourization of DB MR and DY SG by bacterial strain was observed till 5th day, according to Pokharia and Ahluwalia [16]. The dye discoloration was measured with a UV spectrophotometer every 24 hour interval during the discoloration process. The mixture of dyes was prepared by adding reactive, disperse and direct dyes (100 $\mathrm{mg} / \mathrm{L}$ concentration of each dye; Direct Brown MR and Direct Yellow SG. Decolourization was measured at $\lambda$ max of the dye mixture. The selection of suitable wavelength in the spectrum can be made during the course of preparing of the calibration curve for the unknown samples. The particular wavelength which provides a maximum absorbance value will be considered as the best choice of wavelength. Reactive dye solutions show maximum absorbance at a wavelength of $450 \mathrm{~nm}$. The decrease in absorbance was monitored at $\lambda$ max for the particular dye. Decolorized sample $(5 \mathrm{ml})$ withdrawn periodically, was centrifuged at $10000 \mathrm{rpm}$ for $15 \mathrm{~min}$ and its absorbance was 
Citation: Kumar RL, Krishnaswamy VG. Removal of Mixed Azo Dyes by a Moderately Alkaliphilic Bacterial Strain Isolated from Textile Effluent Contaminated Site. J Microbiol Microb Technol 2016;1(1): 9.

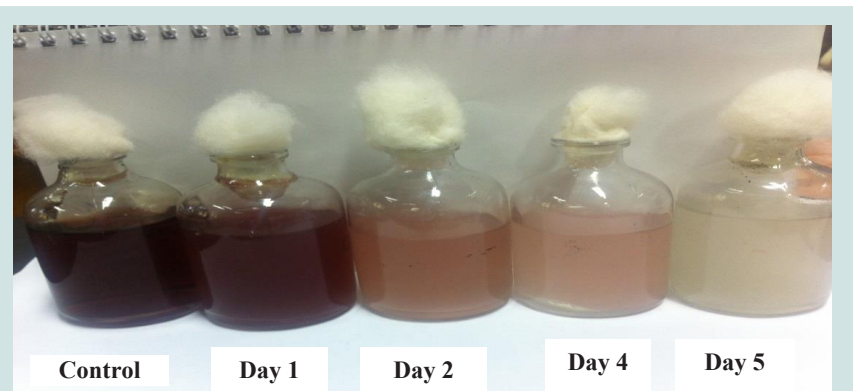

Figure 3: Decolourization of mixed dyes by the isolated bacterial strain at $150 \mathrm{mg} / \mathrm{L}$.

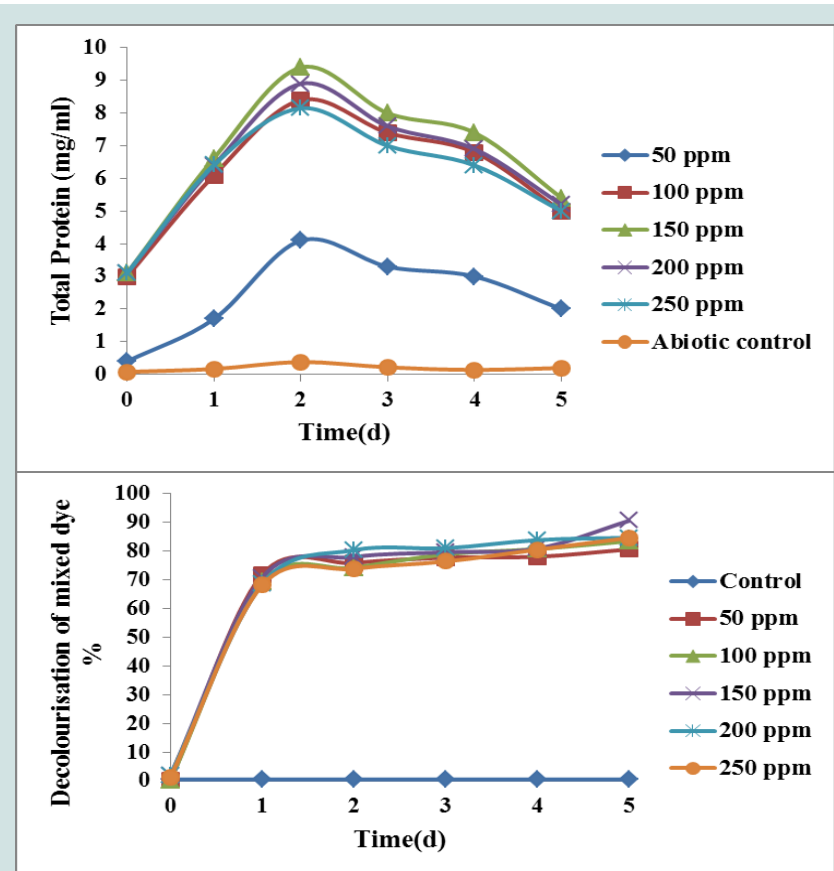

Figure 4: Total protein and decolourization of different concentrations of DB MR and DY SG.

measured at $\lambda$ max of the dye. The uninoculated dye free medium was used as blank. All assays were performed in duplicates and compared with the un-inoculated control. The colour removal efficiency of the bacterial consortium was determined as follows [16]:

Decolourization $(\%)=\frac{\text { Intial absorbance }- \text { Final absorbance }}{\text { Intial absorbance }} \times 100$

\section{Measurement of total protein using Barford's method}

Total cell protein was analysed by centrifuging the samples at 12,000 rpm for $10 \mathrm{~min}$ and washed with fresh (substrate-free) mineral medium, then centrifuged and washed few times to remove the substrate. The pellet from each sample was then disrupted by sonication at $30 \%$ amplitude for a total of $3 \min (1.5 \mathrm{~min} \times 2)$ on an ice-water bath. Sample $(0.5 \mathrm{ml})$ was added to $0.5 \mathrm{~mL}$ Coomassie Blue protein dye and the absorbance were measured at $595 \mathrm{~nm}$. The total protein concentration was determined by calibration with bovine serum albumin standard according to Bradford [17].
In order to study the effect of $\mathrm{pH}$ and temperature, the sterilized MSM was amended with $150 \mathrm{mg} / \mathrm{L}$ of each of the DB MR and DY SG dyes. The medium was maintained at different $\mathrm{pH}: 8,8.5,9,9.5$, and 10. A volume of $1 \mathrm{~mL}$ of overnight culture was inoculated in the flasks and incubated in a shaker at $36{ }^{\circ} \mathrm{C}$. The effect of temperature was studied by inoculating overnight culture and incubating in a shaker at $28^{\circ} \mathrm{C}, 36^{\circ} \mathrm{C}$, and $45^{\circ} \mathrm{C}$. The medium was maintained at $\mathrm{pH}$ 9.5. The measurement of decolourization of the total dye concentration was performed at an interval of $24 \mathrm{~h}$ for 5 days.

\section{Effect of carbon and nitrogen sources on the decolourization of mixed dyes}

The effect of carbon sources was studied using various compounds, such as sucrose, galactose, maltose and xylose at a concentration of $1 \%$ and they were added individually as a supplement to MSM for the decolourization of mixed dyes. A Volume of $1 \mathrm{ml}$ of the overnight culture was inoculated in the flasks and incubated in a shaker at $37^{\circ} \mathrm{C}$. Nitrogen sources like yeast extract, peptone, Tween 20, yeast extract and $\mathrm{NH}_{4} \mathrm{NO}_{3}$ at a concentration of $1 \%$ was substituted to the MSM and the growth and decolourization of the mixed dyes was measured as above. Optimum carbon and nitrogen source i.e. sucrose and yeast extract at a concentration of ( $1 \%$ and $1 \%)$ were substituted to MSM and the growth and decolourization of the mixed dyes was measured.

\section{FT-IR analysis}

The control and samples obtained on Day 1 and Day 5 were extracted with ethyl acetate were dried and mixed with $\mathrm{KBr}(1: 20$; $0.02 \mathrm{~g}$ of sample with $\mathrm{KBr}$ at a final weight of $0.4 \mathrm{~g})$. The samples were then ground, desorbed at $60{ }^{\circ} \mathrm{C}$ for $24 \mathrm{~h}$ and pressed to obtain IR-transparent pellets.

The absorbance FT-IR spectra of the samples were recorded using an FT- IR Spectrum 2000 Perkin-Elmer spectrometer. The spectra were collected within a scanning range of $400-4000 \mathrm{~cm}^{-1}$. The FTIR was first calibrated for background signal scanning with a control

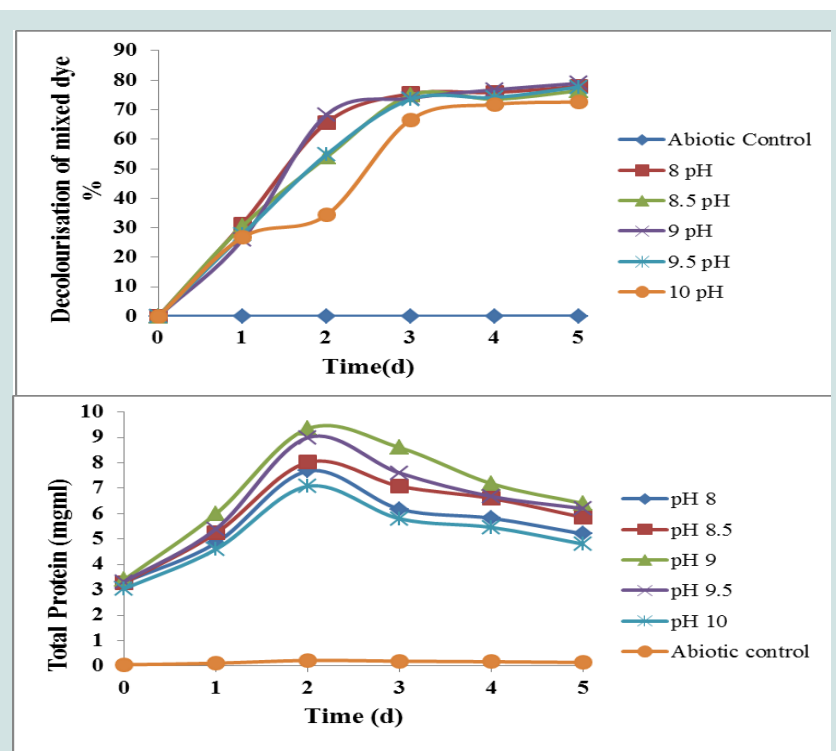

Figure 5: Effect of $\mathrm{pH}$ on total protein content and decolourization of mixed dyes (150 mg/L). 
Citation: Kumar RL, Krishnaswamy VG. Removal of Mixed Azo Dyes by a Moderately Alkaliphilic Bacterial Strain Isolated from Textile Effluent Contaminated Site. J Microbiol Microb Technol 2016;1(1): 9.

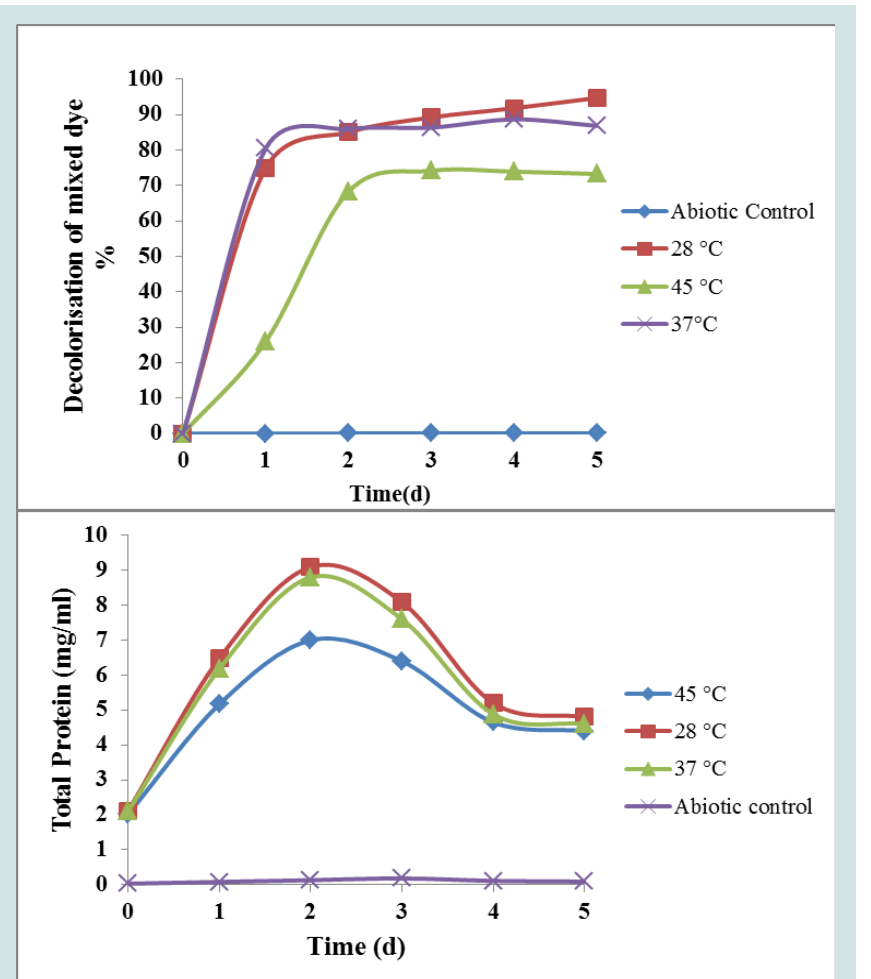

Figure 6: Effect of temperature on total protein content and decolourization of mixed dyes (150 mg/L).

sample of pure $\mathrm{KBr}$ and then the experimental sample was scanned. The FT-IR spectrum of the control was finally subtracted from the spectra of the non-degraded and degraded dyes.

\section{Biochemical characterization}

The bacterial strain isolated was studied for morphological and biochemical characteristics. Initially, Gram staining and motility test were performed after which biochemical characterization was done (with Himedia, India) to identify the phenotypic characters of the bacterial strains. Catalase, Oxidase, Urease, IMViC and Triple sugar iron agar tests were performed to determine the biochemical characteristics of the isolate. After $24 \mathrm{~h}$ incubation at $37^{\circ} \mathrm{C}$, the colour change observed was determined as positive/negative result. Genus level identification of the unknown bacterial strain was accomplished by using Bergey's Manual of Systematic Bacteriology [18].

\section{Molecular characterization}

Chromosomal DNA was isolated from the pure strain by the standard phenol/chloroform extraction method. The 1.2 kilo base partial sequence of the 16S rRNA gene was amplified from the chromosomal DNA using polymerase chain reaction (PCR) with universal Eubacteria-specific primers 16F27 (5'- CCA GAG TTT GAT CMT GGC TCA G - 3') and 16R1525XP (5'- TTCTGCAGT CTA GAA GGA GGT GWT CCA GCC -3'). The PCR conditions used were an initial denaturation at $94{ }^{\circ} \mathrm{C}$ for 2 min, followed by 35 cycles of denaturation at $95{ }^{\circ} \mathrm{C}$ for $1 \mathrm{~min}$, annealing at $55^{\circ} \mathrm{C}$ for 1 min, and extension at $72{ }^{\circ} \mathrm{C}$ for $1 \mathrm{~min}$, and a final extension at $72{ }^{\circ} \mathrm{C}$ for 10 min and sequenced on an ABI310 automated DNA sequencer using the BigDye Terminator kit (Applied Biosystems 3730 x DNA
Analyzer). The amplified 16S rRNA gene PCR products from these isolates were directly sequenced after purification by precipitation with polyethylene glycol and $\mathrm{NaCl}$. The primers used to obtain the complete sequence of $16 \mathrm{~S}$ rRNA gene of the isolates were the same as for PCR amplification (16F27N and 16R1525XP).

Sequence data analysis was done using ChromasPro and Sequencing Analysis software. Further, phylogenetic tree was constructed using MEGA6. The evolutionary history was inferred using the neighbour-joining method. The optimal tree with the sum of branch length $=0.04720271$ is shown. The tree is drawn to scale, with branch lengths (next to the branches) in the same units as those of the evolutionary distances used to infer the phylogenetic tree. The evolutionary distances were computed using the maximum composite likelihood method and are in the units of the number of base substitutions per site. The analysis involved 14 nucleotide sequences. Codon positions included were $1^{\text {st }}+2^{\text {nd }}+3^{\text {rd }}+$ Noncoding. All positions containing gaps and missing data were eliminated. There were a total of 694 positions in the final dataset. Evolutionary analyses were conducted using MEGA6.

\section{Results and Discussion}

The combined effect of an increase in the number of industries and development has led to an increase in industrial based pollutants which pose a serious threat to the ecosystem and human health. Textile industries occupy a large section of the total industries and are a major contributor to wastewater. This coloured
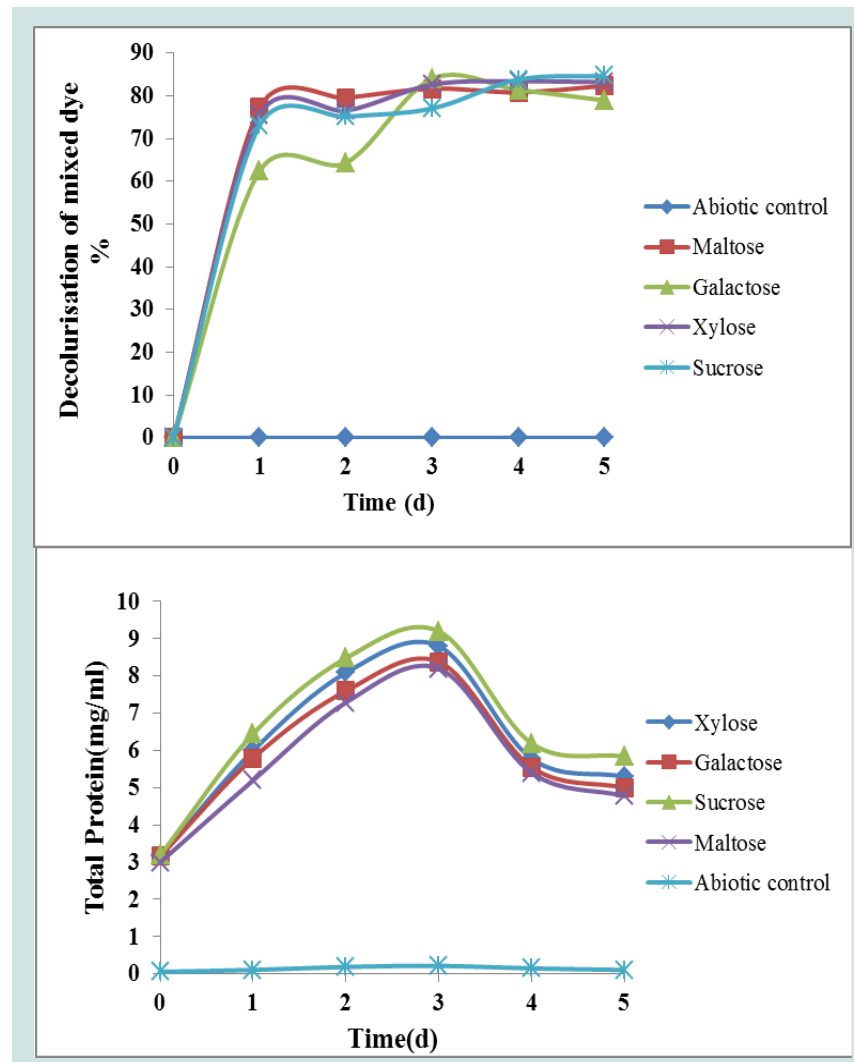

Figure 7: Effect of carbon sources on total protein content and decolourization of mixed dyes $(150 \mathrm{mg} / \mathrm{L})$. 
Citation: Kumar RL, Krishnaswamy VG. Removal of Mixed Azo Dyes by a Moderately Alkaliphilic Bacterial Strain Isolated from Textile Effluent Contaminated Site. J Microbiol Microb Technol 2016;1(1): 9.
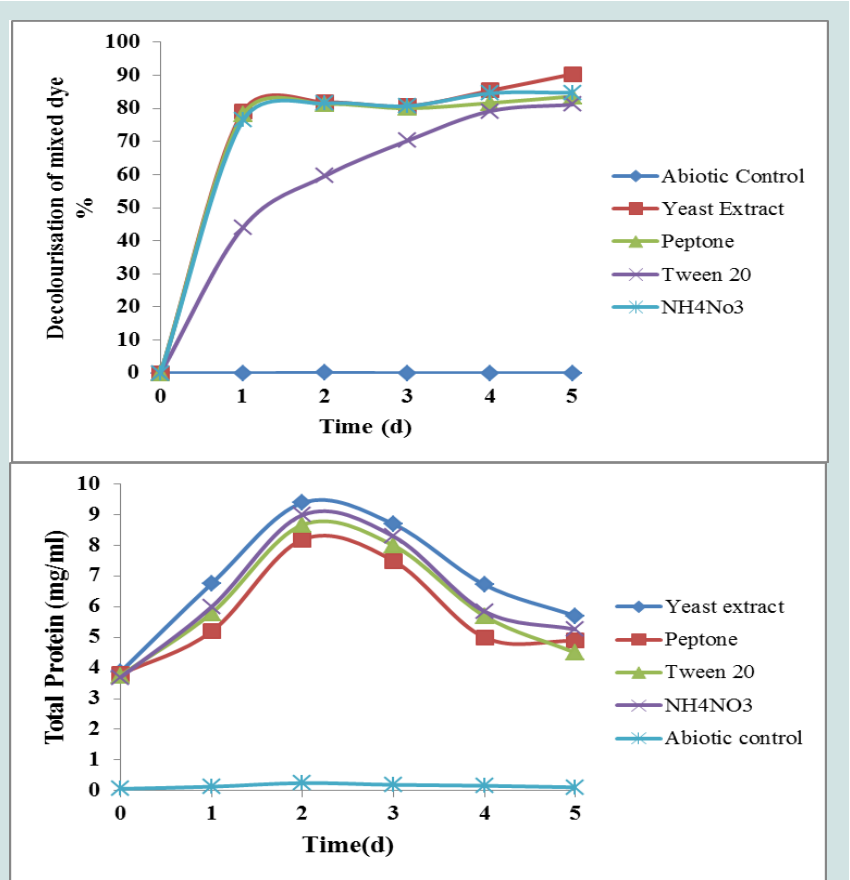

Figure 8: Effect of nitrogen sources on total protein content and decolourization of mixed dyes (150 $\mathrm{mg} / \mathrm{L})$.

wastewater from textile industries contain a high percentage of azo dyes which are increasingly used because of their ease of application and cost effectiveness when compared to natural dyes [19].

Textile wastewater is also potentially carcinogenic and harmful, which if untreated is discharged into the ecosystem either by seepage into aquifers to underground water bodies or into established mainstream water bodies. Physico-chemical treatment methods have managed to remove the effluent from the water to a certain extent, but have also aggravated the problem by introducing secondary effluent through chemicals used in the effluent treatment. This has led man to turn back to Mother Nature to try, where application of microorganisms in the treatment of various industrial wastes, including dye containing effluent have been investigated for the last two decades [20]. This study aims to isolate alkaliphilic bacterial strain that can be used for the removal of mixed dyes as textile wastes tend to have high $\mathrm{pH}$.

\section{Screening and isolation of bacterial strain degrading the $D B$ MR and DY SG}

During the enrichment period, about three bacterial strains were able to survive on the mixed azo dyes (DB MR and DY SG) at a concentration of $100 \mathrm{mg} / \mathrm{L}$ under alkaline condition. After successive transfers only single bacterial strain labelled (RLK 1) utilized mixed azo dyes as a sole carbon and energy source. Figure 2 shows that there was an increase in the viable cell count of the strain from $1^{\text {st }}$ day to $2^{\text {nd }}$ day. By the end of the $3^{\text {rd }}$ day, there was a decrease in viable cell count and bacterial strain could not survive after the $5^{\text {th }}$ day. Hence, for the further experiments, the growth and decolourization of mixed dyes was analyzed at the end of $5^{\text {th }}$ day. Decolourization of the mixed dyes was carried out from $50 \mathrm{mg} / \mathrm{L}$ concentration to $250 \mathrm{mg} / \mathrm{L}$ as the mixed dyes in the textile effluent existed from 50 to $500 \mathrm{mg} / \mathrm{L}[8,13,14]$.

The decolourization of the mixed azo dyes (DB MR and DY SG) by the isolated bacterial strain decreased to $84 \%$ when the concentration was increased to $250 \mathrm{mg} / \mathrm{L}$. Several research works have shown that increase in the concentration of substrates (dyes) from its optimum level has a negative effect on the decolourization capacity of the isolates. Several investigations on decolourization at different dye concentrations have shown higher net colour removal at lower concentrations of dyes $[18,21,22]$. In this study as well, the isolated bacterial strain showed maximum decolourization of the mixed azo dyes (DB MR and DY SG) at concentration of $150 \mathrm{mg} / \mathrm{L}$ respectively which were found to be $90 \%$ by the end of $5^{\text {th }}$ day.

\section{Mixed Azo-Dyes (DB MR and DY SG) decolourization by the bacterial strain}

The ability of the isolated bacterial strain to utilize DB MR and DY SG as a sole carbon and energy source was studied at $50 \mathrm{mg} / \mathrm{L}$ to $250 \mathrm{mg} / \mathrm{L}(50 \mathrm{mg} / \mathrm{L}, 100 \mathrm{mg} / \mathrm{L}, 150 \mathrm{mg} / \mathrm{L}, 200 \mathrm{mg} / \mathrm{L}$ and 250 $\mathrm{mg} / \mathrm{L}$ ). The rate of decolourization increased with increase in initial dye concentration from 50 to $150 \mathrm{mg} / \mathrm{L}$, whereas decolourization decreased at $250 \mathrm{mg} / \mathrm{L}$. The mixed azo dyes at $50 \mathrm{mg} / \mathrm{L}$ of concentration showed decolourization up to $80 \%$ by the end of the $5^{\text {th }}$ day. This was followed by $100 \mathrm{mg} / \mathrm{L}$ of concentration of mixed dyes, which showed decolourization up to $83 \%$, at $150 \mathrm{mg} / \mathrm{L}$ of concentration maximum dyes which increased from the $1^{\text {st }}$ day to $2^{\text {nd }}$ day ( 6.62 to $\left.9.4 \mathrm{mg} / \mathrm{ml}\right)$. The increase in the total protein content and removal of mixed dyes at various concentrations is mentioned in the Figure 3. When the concentration of mixed dyes was increased to $250 \mathrm{mg} / \mathrm{L}$, there was reduction in the decolourization of the mixed dyes to $84 \%$ and there was a corresponding decrease in total protein content ( 8.15 to $6.41 \mathrm{mg} / \mathrm{ml}$ from Day 1 to Day 2. Figure 4 shows the decolourization of mixed dyes at various concentrations.

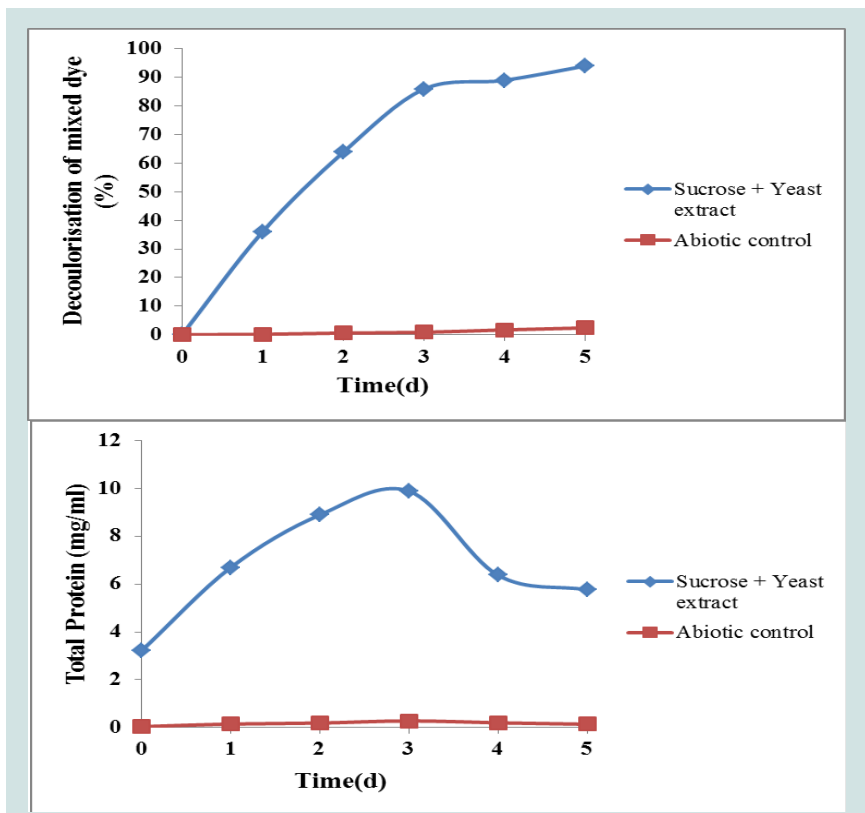

Figure 9: Effect of sucrose and yeast extract on total protein content and decolourization of mixed dyes (150 mg/L). 
Citation: Kumar RL, Krishnaswamy VG. Removal of Mixed Azo Dyes by a Moderately Alkaliphilic Bacterial Strain Isolated from Textile Effluent Contaminated Site. J Microbiol Microb Technol 2016;1(1): 9.

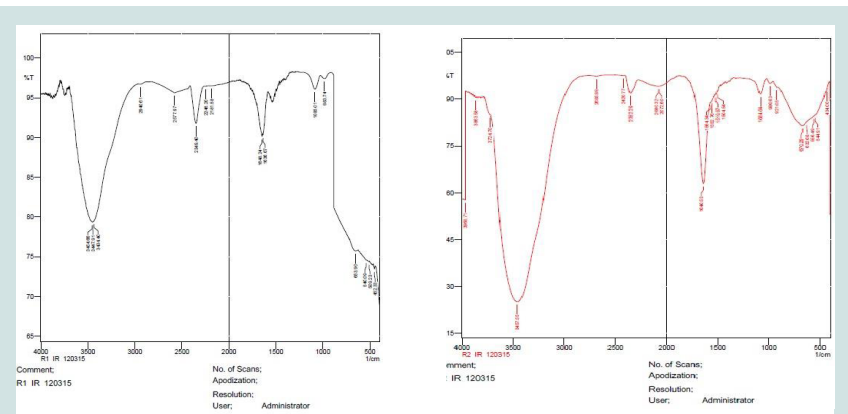

Figure 10: FT-IR spectrum of original mixed dye and decolourized mixed dye (48 hours).

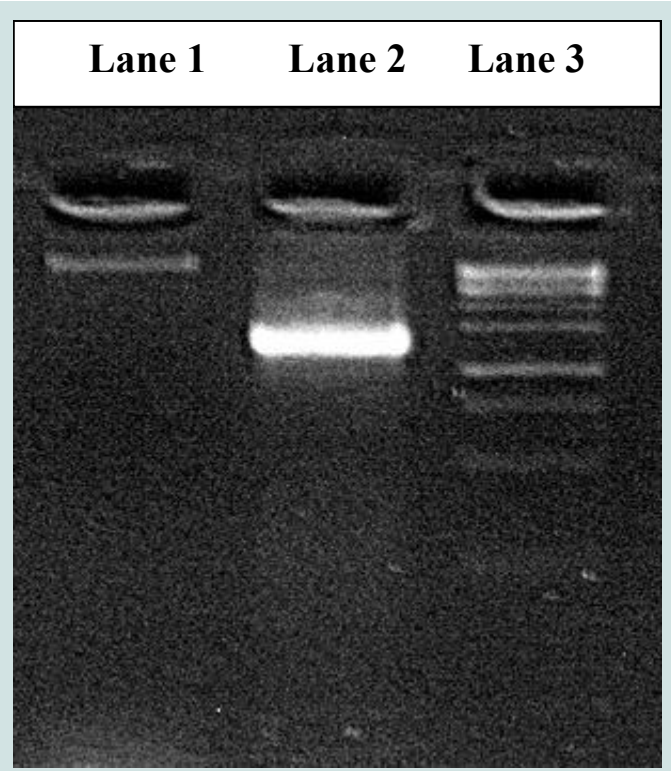

Figure 11: Genomic DNA and PCR amplified products; Lane 1 = Genomic DNA of RLK1; Lane 2 = PCR amplified product of RLK1; Lane $3=1 \mathrm{~kb}$ DNA ladder.

\section{Effect of $\mathrm{pH}$ on the decolourization of mixed dyes}

Alkaline $\mathrm{pH}$ plays an important role in the metabolism of alkaliphilic bacteria. The study was carried out to determine the effect of $\mathrm{pH}$ ( $\mathrm{pH} 8, \mathrm{pH} 8.5, \mathrm{pH} 9, \mathrm{pH} 9.5$ and $\mathrm{pH}$ 10) on the decolourization of mixed dyes at optimum concentration of $150 \mathrm{mg} / \mathrm{L}$ respectively. The increase in the total protein content and the removal of mixed dyes at various $\mathrm{pH}$ is mentioned in the Figure 5. Maximum decolourization was observed at $\mathrm{pH} 9(78 \%)$ and minimize discoloration was observed at $\mathrm{pH} 10$ which was found to be $72 \%$ by the end of the $5^{\text {th }}$ day. Total protein content was found to be maximum at $\mathrm{pH} 9(6 \mathrm{mg} / \mathrm{ml}$ to 9.35 $\mathrm{mg} / \mathrm{ml})$. These results proved that the isolated bacterial strain was alkaliphilic in nature. Decolourization of mixed dyes $(150 \mathrm{mg} / \mathrm{L})$ by the isolated bacterial strain at $\mathrm{pH} 9$ is represented in Figure 5.

$\mathrm{pH}$ of the medium is one of the most important parameters for any microbial processes. The $\mathrm{pH}$ tolerance of decolourizing bacteria is quite important because reactive azo dye bind to cotton fibers by addition or substitution mechanisms under alkaline condition and high temperatures [23]. Several studies have shown decolourization of dyes at varying optimum $\mathrm{pH}$ based on the organisms isolated. A study of bio decolourization of mixed dyes by Rashid Mohammed et al. has shown decolourization by the isolates in the range of $\mathrm{pH} 6$ to 9 with optimum $\mathrm{pH}$ being $\mathrm{pH} 7$ [1].

Prasad and Rao reported Bacillus cohnii MTCC 3616 showed degradation of $95 \%$ efficiency at $\mathrm{pH} 9$ in $4 \mathrm{~h}$ under static conditions. The effects of various $\mathrm{pH}$ on decolourization of Ranocid Fast Blue (RFB) and Procion Brilliant Blue-H-GR (PBB-HGR) were studied with Serratia marcescens and found that the bacteria can decolorize the dyes over a wide range of $\mathrm{pH}$ (5 to 9) with optimum at $\mathrm{pH} 7$ [21]. In the present study, the isolated bacterial strain showed maximum decolourization of mixed dyes (DB MR and DY SG) up to $78 \%$ at $\mathrm{pH}$ 9 at the end of $5^{\text {th }}$ day.

\section{Effect of temperature on the decolourization of mixed dyes}

Temperature is one of the most important parameters, in the decolourization of dyes. It plays important role in microbial growth and enzyme activity. The dye decolourization activity of strain was found to be maximum at $28{ }^{\circ} \mathrm{C}(94 \%)$. The temperature $45{ }^{\circ} \mathrm{C}$ showed the least decolourization of mixed dyes which was found to be $73 \%$ (Figure 6). The temperature $28{ }^{\circ} \mathrm{C}$ was found to be the optimum concentration for efficient decolourization of mixed dyes. Total protein content was found to be maximum at $28^{\circ} \mathrm{C}(6.48 \mathrm{mg} /$ $\mathrm{ml}$ to $9.1 \mathrm{mg} / \mathrm{ml}$ from Day 1 to Day 2). Decolourization of mixed dyes decreased with increase in incubation temperature at 28 to 45 ${ }^{\circ} \mathrm{C}$. Decolourization of mixed dyes by the bacterial strain at $28{ }^{\circ} \mathrm{C}$ is represented in Figure 6.

According to a study conducted by Rashid Mohammed et al. the effects of various temperatures $\left(27\right.$ to $\left.47^{\circ} \mathrm{C}\right)$ on decolourization of mixed dyes by bacterial consortium, was studied in which their results suggested that optimum colour removal was at $37^{\circ} \mathrm{C}[1]$. Pradeep Varma reported on the effect of various temperatures (25 to $50{ }^{\circ} \mathrm{C}$ ) on decolourization of Ranocid Fast Blue (RFB) and Procion Brilliant Blue-H-GR (PBB-HGR) by Serratia marcescens they have observed faster decolourization at $26^{\circ} \mathrm{C}$ within $24 \mathrm{~h}$ incubation [24]. In the present study, the optimum temperature for decolourization of mixed dyes by the isolated bacterial strain was found to be $28^{\circ} \mathrm{C}$ which showed decolourization up to $94 \%$ by the end of $5^{\text {th }}$ day. Optimizations of temperatures by Klebsiella sp. showed decolourization at $37^{\circ} \mathrm{C}$, no decolourization was observed at $47^{\circ} \mathrm{C}$ similar report was observed $[24,25]$.

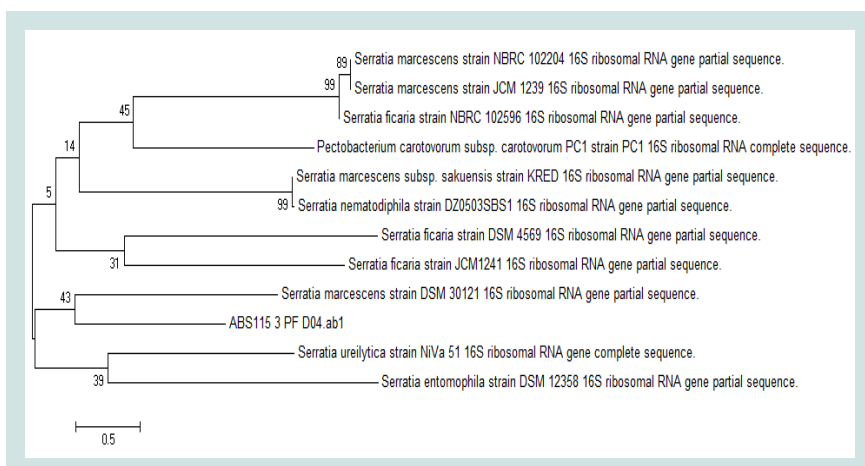

Figure 12: Phylogenetic analysis of Serratia marcescens JCM 1239 strain with its nearby substrains. The numbers at the nodes represent bootstrap values (500 replicates). 
Citation: Kumar RL, Krishnaswamy VG. Removal of Mixed Azo Dyes by a Moderately Alkaliphilic Bacterial Strain Isolated from Textile Effluent Contaminated Site. J Microbiol Microb Technol 2016;1(1): 9.

\section{Effect of carbon sources on the decolourization of mixed dyes}

To examine the influence of carbon sources on the decolourization of mixed dyes at optimum concentrations $(150 \mathrm{mg} / \mathrm{L})$, carbon sources like sucrose, galactose, xylose and maltose were supplemented in the MSM along with DB MR and DY SG. Figure 7 shows that, almost all the carbon sources were able to enhance the decolourization of mixed dyes. An increase in decolourization was observed in the presence of sucrose as carbon source which showed maximum decolourization up to $84 \%$ by the end of $5^{\text {th }}$ day. This was followed by xylose, maltose and galactose which showed $83 \%, 82 \%$ and $78 \%$ of decolourization respectively by the end of the $5^{\text {th }}$ day. Total protein content was found to be maximum with sucrose $(6.45 \mathrm{mg} / \mathrm{ml}$ to $9.2 \mathrm{mg} / \mathrm{ml}$ from Day 1 to Day 2).

Ponraj et al. have reported the range of activity on decolourization of orange 3R with $1 \%$ sucrose as carbon source by Bacillus sp., Klebsiella sp., Salmonella sp., and Pseudomonas sp., showing decolourization of $87.80 \%, 72.36 \%, 86.18 \%$ and $80.49 \%$ respectively with the bacterium Bacillus sp. as the most effective decolourizer with sucrose as carbon source [26]. Among the carbon sources used in the present study for optimization of decolourization, sucrose could enhance the growth of the bacterial consortium more effectively when compared to other carbon sources used.

\section{Effect of nitrogen sources on the decolourization of mixed dyes}

The influence of nitrogen sources on the decolourization of mixed dyes at optimum concentration $(150 \mathrm{mg} / \mathrm{L})$, various nitrogen sources like yeast extract, peptone, Tween 20 and Ammonium nitrate $\left(\mathrm{NH}_{4} \mathrm{NO}_{3}\right)$ were supplemented in MSM along with DB MR and DY SG at $150 \mathrm{mg} / \mathrm{L}$ respectively. Figure 8 show that the addition of nitrogen sources could enhance the growth and decolourization of mixed dyes. Yeast extract showed the maximum decolourization of $90 \%$ by the end of $5^{\text {th }}$ day. This was followed by $\mathrm{NH}_{4} \mathrm{NO}_{3}$ peptone and Tween 20 which showed decolourization of $84 \%, 83 \%$ and $81 \%$ respectively by the end of $5^{\text {th }}$ day. Total protein content was found

Table 1: Biochemical characteristics of isolated bacterial strain.

\begin{tabular}{|l|c|}
\hline \multicolumn{1}{|c|}{ Characteristics } & RLK 1 \\
\hline Gram staining & Rod \\
\hline Cell shape & + \\
\hline Motility & + \\
\hline Catalase & - \\
\hline Urease & - \\
\hline Indole & + \\
\hline Methyl red & - \\
\hline Voges-Proskauer & + \\
\hline Citrate utilization & + \\
\hline Casein Hydrolysis & + \\
\hline Starch Hydrolysis & Alkaline slant and alkaline \\
\hline Triple sugar iron agar & butt \\
\hline Isolate & Serratia sp. \\
\hline
\end{tabular}

to be maximum in the media supplemented with yeast extract $(6.76$ $\mathrm{mg} / \mathrm{ml}$ to $9.4 \mathrm{mg} / \mathrm{ml}$ from Day 1 to Day 2). Tween 20 supplemented media showed the least decolourization up to $81 \%$ and did not play much role in improving the decolourization of mixed dyes. Nitrogen sources like yeast extract, beef extract and peptone were used and the decolourization was high in Yeast extract reported a Bacillus sp. decolorized by $87 \%$ Orange- $3 \mathrm{R}$ dye of sucrose and Beef extract as carbon and Nitrogen sources [26].

Effect of mixed carbon and nitrogen sources on the decolourization of mixed dyes

To increase the degradation efficiency, ideal carbon and nitrogen used in the previous experiments were combined and mixed and dye degradation was checked at optimum concentration $(150 \mathrm{mg} / \mathrm{L})$. Figure 9 shows that the addition of a combination of yeast extract and sucrose could further enhance the decolourization of mixed dyes which was found to be $94 \%$ by the end of $5^{\text {th }}$ day. Total protein content also increased from $6.7 \mathrm{mg} / \mathrm{ml}$ to $9.9 \mathrm{mg} / \mathrm{ml}$ from Day 1 to Day 2. Combinations of different co-substrates glucose and yeast extract, sucrose and yeast extract showed maximum decolourization activity. Similar work was reported [12,27]. Maulin et al. described the use of Bacillus spp. ETL-1979 for sequential decolourization and detoxication [28].

\section{FT-IR analysis}

The FT-IR spectrum of the original mixed dye (Control) and decolourized mixed dye ( 48 hours) by isolated bacterial strain were compared. The spectrum of the control dye displayed a peak 3418.11 $\mathrm{cm}^{-1}$ for -NH stretching (Figure 10). The stretching between C-N was reported at $2271.30 \mathrm{~cm}^{-1}$ and amide, 5-membered ring peak at 1706.86 $\mathrm{cm}^{-1}$. The peak at $1637.21 \mathrm{~cm}^{-1}$ showed carbonyl stretching vibration. Peak at $1374.15 \mathrm{~cm}^{-1}$ showed unsaturated nitrogen compounds. Peak at $1229.06 \mathrm{~cm}^{-1}$ showed $\mathrm{S}=\mathrm{O}$ stretching vibrations. The peak at $1106.62 \mathrm{~cm}^{-1}$ indicates the aromatic nature. The peak at $616.95 \mathrm{~cm}^{-1}$ showed hydrocarbon chromophore - C - H bending.

The FT-IR spectrum of 48 hours decolorized dye by the isolated bacterial strain (Figure 11) showed a significant change in positions of peak, when compared to the control dye spectrum. A new peak at $1636.59 \mathrm{~cm}^{-1}$ represented $-\mathrm{N}=\mathrm{N}$ - stretching vibration. The $\mathrm{C}-\mathrm{H}$ deformation showed at $1398.13 \mathrm{~cm}^{-1}$. The peak at $3408.37 \mathrm{~cm}^{-1}$ showed $\mathrm{N}$ - H stretching vibration. This change in the functional groups of the mixed dye proved the breakage of the aromatic ring and formation of amino groups which clearly indicated the decolourization of the mixed dyes by the bacterial strain.

\section{Biochemical characterization}

Biochemical characterization of the strain was performed using several tests for the identification of the strains. According to biochemical tests, this strain showed positive result for Catalase, Methyl Red, Citrate and negative result for Urease, Indole, VogesProskauer. An alkaline butt and alkaline slant was observed as a result of Triple sugar agar test. The isolated strain had round shaped colonies with smooth and irregular morphology on the nutrient agar plate. RLK 1 showed small, round and pink colour colonies. The results figured from the biochemical test showed the bacterial strain belongs to the genus Serratia. Table 1 summarizes the results on the 
Citation: Kumar RL, Krishnaswamy VG. Removal of Mixed Azo Dyes by a Moderately Alkaliphilic Bacterial Strain Isolated from Textile Effluent Contaminated Site. J Microbiol Microb Technol 2016;1(1): 9.

biochemical tests of the isolated bacterial strain.

\section{Genomic DNA Extraction and PCR Amplification}

The genomic DNA was isolated from the bacterial isolate. PCR amplification was performed and the unknown bacterial strain was identified through $16 \mathrm{~S}$ rDNA sequencing. The bacterial isolate was identified from the sequence using BLAST tool. Genomic DNA and PCR amplified products of the bacterial isolate are shown in Figure 11.

\section{Phylogenetic analysis}

This bacterial strain belonging to the phyla Proteobacteria, is a motile, gram negative, rod shaped bacteria that are naturally found in soil. RLK 1 strain belongs to Kingdom: Bacteria, Phylum: Proteobacteria, Class: Gamma Proteobacteria, Order: Enterobacteriales, Family: Enterobacteriaceae, Genus: Serratia, Species: S. marcescens.

Phylogenetic analysis based on nucleotide sequences from RLK 1 strain showed a maximum of $99 \%$ identity towards Serratia marcescens strain JCM 1239 (Figure 12). Hence, RLK 1 was identified as Serratia marcescens. Pradeep Varma (2003) reported that a novel dye-decolourizing strain of the bacterium Serratia marcescens efficiently decolourized two chemically different dyes Ranocid Fast Blue (RFB) and Procion Brilliant Blue-H-GR (PBB-HGR) [22]. More than $90 \%$ decolourization of PBB-HGR and RFB was obtained on Day 8 and Day 5 , respectively at $26^{\circ} \mathrm{C}$ under static conditions at $\mathrm{pH} 7.0$ and have shown the phylogenetic tree of $S$. marcescens with related organisms based on 16S rRNA sequences. In this study, phylogenetic analysis of the bacterial isolate from the 16S rRNA sequences have shown that the bacterial isolate belong to the genus Serratia and have raised from a common ancestor [29].

The results obtained from the present study showed that the isolated moderately alkaliphilic bacterial strain could decolourize the textile azo dyes (DB MR and DY SG) under aerobic conditions. However the future work on the identification of gene present in the bacterial strains could help in enhancing the decolourization of azo dye. This isolated bacterial strain could finally be used in the treatment of wastewater containing mixed azo dyes.

\section{Conclusion}

Since the levels of wastes produced are increasing with the rise in the water pollutants that are often difficult and costly to treat, we can conclude that the usage of dye degrading bacteria to degrade dyes and reduce their toxicity is a cheaper, more efficient, environmentally friendly and less expensive method and may serve as a good alternative for dye removal from industrial wastewaters.

Biological approach towards dye decolourization has been found to be conducive and cost effective when compared to physicalchemical methods of dye removal. There are no chemicals or harmful substances that are used in biodecolourization of dyes and hence toxicity level is even more reduced. From this present study, it can be concluded that enriched moderately alkaliphilic bacterial strain can be used for decolourizing mixed azo-dyes (DB MR and DY SG) at an optimum concentration of $150 \mathrm{mg} / \mathrm{L}$. The bacterial strain exhibited maximum decolourization ability of mixed dyes at $\mathrm{pH} 9$ and at a concentration of $150 \mathrm{mg} / \mathrm{L}$ of DB MR and DY SG and at an optimum temperature at $28{ }^{\circ} \mathrm{C}$. Supplementing the media with sucrose and yeast extract could greatly enhance the dye decolourization ability of the bacterial strain. On the basis of these results, the bacterial strain can be applied in biological systems for effective removal of the mixed azo dyes in wastewater.

\section{References}

1. Mahmood R, Sharif F, Ali S, Hayyat MU (2015) Enhancing the decolorizing and degradation ability of bacterial consortium isolated from textile effluent affected area and its application on seed germination. ScientificWorldJournal 2015: 628195.

2. Lin SH (1993) Adsorption of disperse dye by powdered activated carbon. J Chem Technol Biotechnol 57: 387-391.

3. Shaw CB, Carliell CM, Wheatley AD (2002) Anaerobic/aerobic treatment of coloured textile effluents using sequencing batch reactors. Water Res 36 : 1993-2001

4. Basava Rao VV, Ram Mohan Rao S (2006) Adsorption studies on treatment of textile dyeing industrial effluent by flyash. Chem Eng J 116: 77-84.

5. Liu R, Chiu HM, Shiau CS, Yeh RY, Hung YT (2007) Degradation and sludge production of textile dyes by Fenton and photo-Fenton processes. Dyes Pigm 73: $1-6$.

6. Yang Q, Yediler A, Yang M, Kettrup A (2005) Decolourization of an azo dye, reactive black 5 and MnP production by yeast isolate: Debaryomyces polymorphus. Biochem Eng J 24: 249-253.

7. Chang JS, Lin CY (2001) Decolourization kinetics of a recombinant Escherichia coli strain harboring azo-dye- decolorizing determinants from Rhodococcus sp. Biotechnol Lett 23: 631-636.

8. Pearce Cl, Lloyd JT, Guthrie JT (2003) The removal of colour from textile waste water using whole bacteria cells: a review. Dyes Pigm 58: 179-196.

9. Carvalho MC, Pereira C, Goncalves IC, Pinheiro HM, Santos AR, et al (2008) Assessment of the biodegradability of a monosulfonated azo dye and aromatic amines. Int Biodeterior Biodegradation 62: 96-103.

10. Parshetti G, Kalme S, Saratale G, Govindwar S (2006) Biodegradation of malachite green by Kocuria rosea MTCC 1532. Acta Chim Slov 53: 492-498.

11. Park S, Ryu JY, Seo J, Hur HG (2012) Isolation and characterization of alkaliphilic and thermotolerant bacteria that reduce insoluble indigo to soluble leuco- indigo from Indigo Dye Vat. J Korean Soc Appl Biol Chem 55: 83-88.

12. Gurulakshmi M, Sudarmani DN, Venba R (2008) Biodegradation of leather acid dye by Bacillus subtilis. Adv Bio Tech 7.

13. Olukanni OD, Osuntoki AA, Gbenle GO (2006) Textile effluent biodegradation potentials of textile effluent-adapted and non-adapted bacteria. Afr J Biotechnol 5: 1980-1984.

14. Pandey A, Singh $P$, lyengar $L$ (2007) Bacterial decolorization and degradation of azo dyes. Int Biodeterior Biodegradation 59: 73-84.

15. Levin L, Papinutti L, Forchiassin F (2004) Evaluation of Argentinean white rot fungi for their ability to produce lignin-modifying enzymes and decolorize industrial dyes. Bioresour Technol 94: 169-176

16. Pokharia A, Ahluwalia SS (2013) Isolation and screening of dye decolorizing bacterial isolates from contaminated sites. Text Light Ind Sci Technol 2: 5461.

17. Bradford MM (1976) A rapid and sensitive method for quantitation of microgram quantities of protein utilizing the principle of protein-dye binding. Anal Biochem 72: 248-254

18. Brenner DJ, Kreig NR, Staley JT (2005) The proteobacteria. In: Garrity G (Ed.), Bergey's manual of systematic bacteriology, Volume 2, Springer, Newyork.

19. Mahmood S, Arshad M, Khalid A, Nazli ZH, Mahmood T (2011) Isolation and screening of azo dye decolorizing bacterial isolates from dye-contaminated 
Citation: Kumar RL, Krishnaswamy VG. Removal of Mixed Azo Dyes by a Moderately Alkaliphilic Bacterial Strain Isolated from Textile Effluent Contaminated Site. J Microbiol Microb Technol 2016;1(1): 9.

\section{ISSN: $2474-4530$}

textile wastewater. Soil Environ 30: 7-12.

20. Asamudo NU, Daba AS, Ezeronye OU (2005) Bioremediation of textile effluent using Phanaerochaete chrysosporium. Afr J Biotechnol 3: 1548 $-1553$

21. Prasad AS, Rao KV (2013) Aerobic biodegradation of azo dye by Bacillus cohnii MTCC 3616; an obligately alkaliphilic bacterium and toxicity evaluation of metabolites by different bioassay systems. Appl Microbiol Biotechnol 97: 7469-7481.

22. Varma P, Madamwar D (2003) Decolourization of synthetic dyes by a newly isolated strain of Serratia marscecens. World J Microbiol Biotechnol 19: 615618

23. Sponza DT, Isik M (2005) Reactor performances and fate of aromatic amines through decolorization of Direct Black 38 dye under anaerobic/aerobic sequential. Process Biochem 40: 35-44.

24. Joshi B, Kabariya K, Nakrani S, Khan A, Parabia FM, et al. (2013)
Biodegradation of turquoise blue dye by Bacillus megaterium isolated from industrial effluent. Am J Environ Prot 1: 41-46.

25. Praveen Kumar GN, Bhat Sumangala K (2012) Decolourization of azo dye red $3 \mathrm{BN}$ by bacteria Int Res J Biol Sci 1: 46-52.

26. Ponraj M, Gokila K, Zambare V (2011) Bacterial decolourization of textile dyeOrange 3R. Int J Adv Biotechnol Res 2: 168-177.

27. Sahasrabudhe MM, Pathade GR (2011) Biodegradation of sulphonated azo dye C.I. reactive orange 16 by Entercoccus faecalis strain YZ 66. Eur J Exp Biol 1: 163-173.

28. Shah MP, Patel KA, Nair SS, Darji AM (2014) Microbial degradation and decolorization of reactive dyes by Bacillus spp. ETL-1979. Am J Microb Res 2: 16-23.

29. Rajeshwari K, Subashkumar R, Vijayaraman K (2011) Biodegradation of mixed textile dyes by bacterial strains isolated from dyewaste effluent. Res $\mathrm{J}$ Environ Toxicol 5: 97-107. 